\title{
Effect of dietary vitamin A level on performance, vitamin A content in the liver and leg weakness of growing finishing pigs
}

\author{
Timo Alaviuhkola, Kaija Suomi and Axel Schulman
}

\begin{abstract}
Alaviuhrola, T., Suomi, K. \& Schulman, A. 1992. Effect of dietary vitamin A level on performance, vitamin A content in the liver and leg weakness of growing finishing pigs. Agric. Sci. Finl. 1: 471-475. (Agric. Res. Centre of Finland, Swine Res. Sta., SF-05840 Hyvinkää, Finland and Nat. Veter. Inst., Hämeentie 57, SF-00580 Helsinki, Finland.)
\end{abstract}

A total of 160 piglets, females and castrates, were divided at weight of $25 \mathrm{~kg}$ into four groups in order to study the effects of dietary vitamin A supplementation. The groups were balanced according to initial weight,sex and litter origin.

The same basic mixture, consisting of barley and commercial protein concentrate with all minerals and vitamins except vitamin $\mathrm{A}$, was used in feeding of all the piglets. The vitamin A activity of the mixture, however, was $646 \mathrm{IU} / \mathrm{kg}$. Special vitamin A premixes were prepared by using a commercial product providing the four final four diets with $0,1000,3000$ and $50000 \mathrm{IU} / \mathrm{kg}$.

Three piglets were sacrificed at the beginning of the trial to determine the content of liver vitamin A. It was found to vary between 7.3 and $10.2 \mathrm{mg} / 100 \mathrm{~g}$ fresh liver.

There were no differences between the groups in daily gain,feed: gain ratio or carcass quality. A histological examination of leg joints did not reveal an increased frequency of osteochondrosis in pigs fed with a high level of vitamin A.

Growing finishing pigs, having adequate liver stores of vitamin A at $25 \mathrm{~kg}$ of live weight, grew without showing any visible signs of deficiency up to $100 \mathrm{~kg}$ weight with no vitamin A additions. However, the liver vitamin A analysis at slaughter showed that the recommendation for vitamin A in practical pig feeds should be higher than 1000 $\mathrm{IU} / \mathrm{kg}$. In the present experiment, $3000 \mathrm{IU} / \mathrm{kg}$ was found to be a sufficient level.

Key words: vitamin A, growing pig, leg weakness

\section{Introduction}

The vitamin A requirement of growing pigs is based on a large number of experiments (ARC 1981). Due to safety margins, the practical recommendations in different countries vary. In Finland the vitamin $\mathrm{A}$ recommendation of vitamin $\mathrm{A}$ for growing finishing pigs is $5000 \mathrm{IU} / \mathrm{kg}$ air dry feed. A high content of vitamin A has been measured in the livers of pigs taken from a practical slaughterhouse line. It can be concluded that some farmers had used vitamin additions several times higher than the recommended level.

Moreover it has been suggested that too generous vitamin A feeding increases osteochondrosis in growing pigs (BLAIR et al.1989).

The consumption of liver and liver products enriched with too much vitamin A can create a health risk to humans, especially to developing embryos (BALLING 1991). For these reasons there is a pressure to lower the vitamin supplementation in pig feeds. 
In earlier Finnish experiments, the vitamin A content of feeds has varied between 2500-20000 $\mathrm{IU} / \mathrm{kg}$. The level of vitamin A in the feed has not been found to have any effect on the performance of growing pigs (AlaviuHKola 1983, PUONTI 1991). In the present experiment, the intention was to study the possibilities for lowering the vitamin A recommendation and to find out if mega levels produced any harmful effects in pigs.

\section{Material and methods}

One hundred and sixty piglets at a live weight of 25 $\mathrm{kg}$ were divided into four groups, and the groups were balanced according to initial weight, sex and litter origin of the animals. The pigs were housed and fed in pairs. The pens were furnished with a concrete floor. Wood shavings were used as the drying material. Females and castrated males were kept separate. To increase the number of leg joints to be inspected, an additional 16 piglets were included in the experiment and treated like the piglets in group four. All the experimental piglets were from the sow unit of the Swine Research Station. They were all free from infectious diseases.

\section{Feeds}

The basic mixture given to all the animals contained barley $(83 \%)$ and a commercial protein, mineral and vitamin concentrate (17\%) with no vitamin A supplement. The main components of the concentrate were soybean meal $(59.4 \%)$ and meat and bone meal (22\%). The measured vitamin A content of the concentrate was $3800 \mathrm{IU} / \mathrm{kg}$, providing the basic feed mixture with $646 \mathrm{IU} / \mathrm{kg}$. All the feeds contained $60 \mathrm{mg}$ of vitamin E and $1100 \mathrm{IU}$ of vita$\min \mathrm{D}$ in one kilogram of air dry feed. Special vitamin A premixes were prepared by Cultor Ltd using a commercial source and providing mixtures 1-4 with $0,1000,3000$ and $50000 \mathrm{IU} / \mathrm{kg}$, in addition to the $646 \mathrm{IU}$ from the natural components of the mixture.

The vitamin premixes were analyzed at Cultor Ltd. Vitamin A analyses from the liver were made at the National Veterinary Institute. The method is described in the paper by HIRVI et al.(1992). Three piglets were slaughtered at the beginning of the trial to determine the pre-experimental vitamin storage in the liver.

The distal point of the femur and the proximal point of the tibia were removed in a partial dissection and studied histologically for groolesions at the National Veterinary Institute. The material was divided into three classes: joints with no changes on the surface, small changes on the surface and clear osteochondrosis. The method of GRöndALEN (1974) was used. Before transporting the pigs to the slaughterhouse, the condition of the legs was scored subjectively using grades $1-5$, where a score of 5 meant perfectly sound and a score of 1 was given if the pig could not walk without help.

The data were subjected to an analysis of variance. The following model was used:

$\mathrm{Y}_{\mathrm{ij}}=\mu+\mathrm{T}_{\mathrm{i}}+\mathrm{S}_{\mathrm{j}}+\mathrm{e}_{\mathrm{ijk}}$, in which

$\mathrm{Y}_{\mathrm{ij}}=$ observation

$\mu=$ overall mean

$\mathrm{T}_{\mathrm{i}}=$ effect of treatment $(\mathrm{i}=1, \ldots, 4)$

$\mathrm{S}_{\mathrm{j}}=$ effect of $\operatorname{sex}(\mathrm{j}=1,2)$

$(\mathrm{TS})_{\mathrm{ij}}=$ treatment $\mathrm{x}$ sex interaction $\mathrm{e}_{\mathrm{ijk}}=$ residual term

The mean of a pen ( 2 animals) was taken as one observation for statistical analysis. Tukey's test was used in pairwise comparisons (SNEDECOR and CoCHRAN 1963).

The results of the vitamin A analysis were handled statistically using an analysis of variance with one-way classification. The result for a single pig represents one observation.

\section{Results and discussion}

The vitamin A level in the liver of the three sacrificed piglets at $25 \mathrm{~kg}$ live weight varied between 7.3 and $10.2 \mathrm{mg} / 100 \mathrm{~g}$ fresh liver. The daily gain, feed conversion efficiency and carcass quality of the pigs is shown in Table 1. One animal was removed from group 3 because of microangiopathia. One pig was lost from group 4 during transportation.

The vitamin A level of the feed had no noticeable 
Table 1. Daily gain, feed consumption and carcass quality of pigs fed with different levels of vitamin A supplementation.

\begin{tabular}{|c|c|c|c|c|c|c|c|c|c|c|c|c|}
\hline \multirow{2}{*}{$\begin{array}{l}\text { Group } \\
\text { Vitamin A IU/kg }\end{array}$} & \multicolumn{2}{|c|}{ I } & \multicolumn{2}{|r|}{ II } & \multicolumn{2}{|c|}{ III } & \multicolumn{2}{|c|}{ IV } & \multicolumn{2}{|c|}{ Sex mean } & \multicolumn{2}{|c|}{ Significance } \\
\hline & $\mathrm{x}$ & cv \% & $\mathrm{x}$ & cv $\%$ & $\mathrm{x}$ & $\operatorname{cv} \%$ & $\mathrm{x}$ & cv $\%$ & Fema & Castrate & $\begin{array}{l}\text { Treat- } \\
\text { ment }\end{array}$ & - Sex \\
\hline Number of animals & 4 & 0 & & 10 & & 9 & & 9 & & & & \\
\hline Initial weight, $\mathrm{kg}$ & 25.0 & 5.00 & 25.0 & 5.24 & 25.0 & 3.78 & 24.8 & 5.13 & 24.7 & 25.2 & NS & * \\
\hline Final weight, kg & 95.1 & 2.69 & 95.3 & 2.36 & 95.6 & 2.54 & 95.5 & 3.03 & 95.3 & 95.4 & NS & NS \\
\hline Daily gain, $\mathrm{g}$ & 850 & 3.23 & 846 & 3.23 & 844 & 2.38 & 852 & 2.85 & 850 & 846 & NS & NS \\
\hline Feed : gain, $\mathrm{FU}^{1}$ & 2.57 & 4.30 & 2.59 & 3.86 & 2.58 & 3.71 & 2.55 & 5.29 & 2.57 & 2.57 & NS & NS \\
\hline Side fat, $\mathrm{mm}$ & 15.3 & 12.7 & 15.4 & 13.4 & 15.8 & 20.3 & 16.1 & 11.9 & 14.5 & 16.8 & NS & $* * *$ \\
\hline Colour of lean, degr. ${ }^{2}$ & 35.6 & 11.40 & 35.6 & 8.83 & 34.5 & 7.98 & 35.0 & 7.70 & 34.9 & 35.5 & NS & NS \\
\hline pH 24h & 5.50 & 2.05 & 5.50 & 1.39 & 5.56 & 3.90 & 5.49 & 1.90 & 5.50 & 5.52 & NS & NS \\
\hline
\end{tabular}

1) $1 \mathrm{FU}=0.7$ Starch Equivalent

2) EEL reflectometer

NS, not significant; *, P $\leq 0.05 ; \mathrm{P} \leq 0.001$

Table 2. Vitamin A content of the liver and the leg condition of pigs fed with different levels of vitamin A supplementation.

\begin{tabular}{|c|c|c|c|c|c|c|c|c|}
\hline \multirow[t]{2}{*}{$\begin{array}{l}\text { Group } \\
\text { Vitamin A, IU/kg }\end{array}$} & \multicolumn{2}{|c|}{$\begin{array}{l}\text { I } \\
0\end{array}$} & \multicolumn{2}{|c|}{$\begin{array}{c}\text { II } \\
1000\end{array}$} & \multicolumn{2}{|c|}{$\begin{array}{c}\text { III } \\
3000\end{array}$} & \multicolumn{2}{|c|}{$\begin{array}{c}\text { IV } \\
50000\end{array}$} \\
\hline & $\mathrm{x}$ & cv \% & $\mathrm{x}$ & cv $\%$ & $\mathrm{x}$ & cv $\%$ & $\mathrm{x}$ & cv $\%$ \\
\hline \multicolumn{9}{|l|}{ Leg score (1-5) } \\
\hline forelegs & 3.45 & 16.2 & 3.78 & 10.1 & 3.75 & 13.3 & 3.58 & 13.1 \\
\hline hind legs & 3.18 & 12.8 & 3.23 & 13.8 & 3.35 & 12.0 & 3.20 & 11.8 \\
\hline $\begin{array}{l}\text { Number of leg joints } \\
\text { examined }\end{array}$ & 17 & & 15 & & 19 & & 20 & \\
\hline $\begin{array}{l}\text { Severe signs of } \\
\text { osteochondrosis, \% }\end{array}$ & 24 & & 7 & & 5 & & 5 & \\
\hline Mild signs, $\%$ & 12 & & 27 & & 16 & & 35 & \\
\hline $\begin{array}{l}\text { Vitamin A content } \\
\text { of liver, } \mathrm{mg} / 100 \mathrm{~g}^{1}\end{array}$ & $2.94^{c}$ & 25.4 & $4.38^{\mathrm{c}}$ & 29.2 & $19.47^{b}$ & 15.8 & $99.10^{\mathrm{a}}$ & 8.2 \\
\hline
\end{tabular}

Means with different superscripts differ significantly $(\mathrm{P}<0.001)$.

effect on growth, feed consumption or carcass quality of the pigs. No symptoms of vitamin A deficiency or overfeeding were observed. The result was in accordance with earlier Finnish results reported by AlaviuHKola (1983) and Puonti (1991). In these experiments the vitamin A level varied between 2500 and $20000 \mathrm{IU} / \mathrm{kg}$ air dry feed. SCHÖNE and LÖDGE (1984) found no differences in the daily gain and feed consumption of pigs between groups when vitamin A supplementation varied between 0 and $8000 \mathrm{IU} / \mathrm{kg}$.

The performance of females was similar to that of castrated males. However, the castrated males were fattier than females $(\mathrm{P}<0.001)$. The vitamin content in the liver and the leg health of the experimental pigs are shown in Table 2. There were significant differences $(\mathrm{P}<0.001)$ in the vitamin $\mathrm{A}$ content in the liver between treatments. The two lowest vitamin A levels were not sufficient to maintain the concentration on the level which was found in the livers of the sacrified piglets. On the other hand, the highest level,about $100 \mathrm{mg} / 100 \mathrm{~g}$ liver, was also reported by HIRVI et al. (1992) found in samples taken from a practical slaughter line. HENNIG et al. (1985) reported a highly significant linear relationship between vitamin A content in 
feed and vitamin A content in the liver. In the present study, a similar relationship was noticed, but the linearity was not tested. HeNNIG et al. also concluded that $800 \mathrm{IU}$ of vitamin $\mathrm{A}$ in the feed for fattening pigs was sufficient to maintain a vitamin A storage of $3500 \mathrm{IU} / 100 \mathrm{~g}$ liver. Below this level, the plasma vitamin A value is reported to decrease.

In the present experiment, $1000 \mathrm{IU} / \mathrm{kg}$ feed seemed to provide pigs with a sufficient vitamin A storage. Taking into consideration the large variation between individual pigs as well as a proper safety margin, such a level cannot be recommended for practical purposes. In the present experiment the initial storage in the liver was large, but that is not always the case in practical pig husbandry.

Examination of leg joints revealed some more or less severe symptoms of osteochondrosis, but the differences between the groups were small. The proportion of completely healthy joints was 64,67 , 79 and $60 \%$ in groups $1-4$, respectively. The grading of the legs at the end of the trial did not indicate any differences in the health of the legs or in the gait of the animals. Incidence of severe ostreochondrosis was the highest in group 1 (4 cases of 17 inspected). The result does not confirm the findings of BLAIR et al. (1989) who reported an increased incidence of osteochondrosis in pigs fed with a high addition of vitamin A (43750 IU/ $/ \mathrm{kg})$. On the other hand, they do support the results found by REILAND (1975), who concluded that the reasonably high incidence of osteochondrosis was not dependent on the vitamin A level in the feed.

\section{References}

Alaviuhkola, T. 1983. Lihasikojen A- ja D-vitamiinien tarve. Koetoim. ja Käyt. 40: 12-13.

ARC 1981. The Nutrient Requirements of Pigs. Commonwealth Agricultural Bureaux, Slough, England. 307 p.

BALLING, R. 1991. CRABP and the teratogenic effects of retinoids. Trends in genetics. 17(2): 35-36.

Blair, R., Burton, B.A., Doige, C.E., Halstead, A.C. \& Newsome, F.E. 1989. Tolerance of Weanling Pigs for Dietary Vitamin A and D. Intern. Vit. Nutr. Res. 59: 329-332.

GröndALEN, T. 1974. Osteochondrosis and arthrosis in pigs. I. Incidence in animals up to $120 \mathrm{~kg}$ live weight. Acta Vet. Scand. 15: 1-25.

Hennig, A., Schöne, F., Lơdge, H., Panndorf, H. \& GeiNITZ, D. 1985. Untersuchungen zum Vitamin-A-bedarf des wachsendes Schweines. Arch. Tierernăhr., Berlin 35(1): 19-31.

Hirvi, T., Lindfors, E., SAARI, L. \& HIRN, J. 1992. Vitamin $\mathrm{A}$ in the liver of some Finnish domestic animals and reindeer. Vår Föda. Svenska Livsmedelverkets Tidskrift. (in press).

PuONTI, M. 1991. A-vitamiini ja sikojen kasvu. Sika 21(1): 8-9.
SCHŌNE, F. \& LỠgE, H. 1984. Untersuchungen zum Vitamin-A-bedarf des wachsendes Schweines. Arch. Tierernähr., Berlin 34(3): 205-218.

REILAND, S. 1975. Osteochondrosis in the pig. Akademisk Avhandling, Stockholm.

SNEDECOR, G.W. \& Cochran, W.G. 1963. Statistical methods. 7 th ed. 597 p. The Iowa state univ. Press, Ames Iowa.

Manuscript received March 1992

Timo Alaviuhkola

Kaija Suomi

Agricultural Research Centre of Finland

Swine Research Station

SF-05840 Hyvinkää, Finland

Axel Schulman

National Veterinary Institute

Hämeentie 57

SF-00580 Helsinki, Finland 


\title{
SELOSTUS
}

\section{Rehun A-vitamiinipitoisuuden vaikutus lihasikojen tuotantoon, maksan A-vitamiinipitoisuuteen ja jalkojen terveyteen}

\author{
Timo Alaviuhkola, Kaija Suomi ja Axel Schulman \\ Maatalouden tutkimuskeskus ja Valtion eläinlääketieteellinen laitos
}

Satakuusikymmentä Y-ja M-rotuista porsasta jaettiin neljaaăn ruokintaryhmäăn. Porsaiden alkupaino oli keskimäärin $25 \mathrm{~kg}$. Ryhmittelyssä otettiin huomioon porsaiden pahnuetausta ja sukupuoli. Ennen koetta porsaat oli ruokittu kaupallisella tăysrehulla ad libitum.

Kokeessa porsaat ruokittiin ohralla ja kaupallisella tiivisteellä, jossa ei ollut A-vitamiinilisäystä. Tiiviste-viljaseoksen A-vitamiiniaktiivisuudeksi mitattiin 646 ky/kg. Kaupallisesta A-vitamiinivalmisteesta tehtiin väkevyydeltään erilaisia esiseoksia, joita lisättiin vilja-tiivisteseoksiin siten, ettă lopullisiin seoksiin saatiin 0, 1000, 3000 ja 50000 ky:ă A-vitamiinia kilossa ilmakuivaa rehua.

Kolme porsasta teurastettiin kokeen alussa. Niiden maksan A-vitamiinipitoisuus oli 7.3-10.2 mg/100 g tuoretta maksaa.
Rehun A-vitamiinipitoisuudella ei ollut vaikutusta sikojen kasvuun tai rehun hyväksikäyttöön sikojen kasvaessa 25 :stả 95:een kiloon. Puutos- tai hypervitaminoosioireita ei voitu silmämäăräisesti havaita. Jalkojen kunnossa tai eläinten liikkumisessa ei havaittu eroja ryhmien vălillä.

Maksan A-vitamiinipitoisuudessa oli erittäin merkitsevät erot ryhmien keskiarvojen välillä. Nivelpintatarkastelussa suurinkaan A-vitamiinitaso ei näyttänyt lisäăvän osteokondroosia.

Tulos osoitti, että lihasiat selviytyvăt runsaiden porsasajan A-vitamiinivarastojen turvin noin kolmen kuukauden pituisen lihasikajakson ilman näkyviä puutosoireita. Maksan varastot kuluvat kuitenkin liian văhăisiksi, ellei rehu sisällä văhintään 3000 ky:ä A-vitamiinia kilossa. 